\title{
ANALISIS KADAR FENOLIK TOTAL DAN AKTIVITAS ANTIRADIKAL BEBAS MADU DAN PROPOLIS Trigona sp. ASAL LOMBOK UTARA
}

\author{
Nur Nadhifah Zahra ${ }^{1}$, Handa Muliasari ${ }^{1 *}$, Yayuk Andayani ${ }^{1}$, I Made Sudarma ${ }^{2}$ \\ ${ }^{1}$ Program Studi Farmasi Fakultas Kedokteran Universitas Mataram \\ ${ }^{2}$ Program Studi Kimia Fakultas Matematika dan Ilmu Pengetahuan Universitas Mataram \\ handamuliasari@unram.ac.id
}

\begin{tabular}{l} 
Artikel Info \\
Diterima \\
tanggal \\
20.11 .2020 \\
Disetujui \\
publikasi \\
tanggal \\
30.04 .2021 \\
Kata kunci : \\
Fenolik, \\
Lombok Utara, \\
Propolis, \\
Trigona sp. \\
\hline
\end{tabular}

\begin{abstract}
ABSTRAK
Eksplorasi madu dan propolis Trigona $s p$ sebagai antioksidan alami semakin ditekuni. Produksi madu dan propolis Trigona $s p$. di Kabupaten Lombok Utara semakin berkembang dengan total koloni sebesar 22.657 pada tahun 2019. Produksi yang melimpah tersebut belum dilengkapi dengan data ilmiah. Penelitian ini bertujuan menentukan kadar fenolik total serta menghitung nilai $\mathrm{IC}_{50}$ dari madu dan propolis Trigona sp. asal Lombok Utara. Ekstrak madu Trigona sp. diperoleh menggunakan teknik sentrifugasi dan ekstrak propolis Trigona sp. menggunakan metode Ultrasound-assisted Extraction (UAE). Kadar fenolik total ditentukan menggunakan metode Folin-ciocalteu dan aktivitas radikal bebas ditentukan menggunakan metode DPPH. Ekstrak madu Trigona $s p$. asal Lombok Utara memiliki kadar senyawa fenolik total sebesar $1,25 \pm 0,08 \mathrm{mg}$ GAE/g, dan Nilai $\mathrm{IC}_{50}$ sebesar $1550 \pm 0,02 \mu \mathrm{g} / \mathrm{ml}$. Ekstrak propolis Trigona $s p$. asal Lombok Utara memiliki kadar senyawa fenolik total ekstrak propolis sebesar 6,02 $\pm 0,55 \mathrm{mg}$ GAE/g, dan Nilai $\mathrm{IC}_{50}$ sebesar 493,3 $\pm 0,01 \mu \mathrm{g} / \mathrm{ml}$.
\end{abstract}

\section{ABSTRACT}

Exploration of honey and propolis Trigona sp. as natural antioxidant are increasingly being pursued. Apiculture of honey and propolis Trigona sp. in North Lombok are expanding with total colony 22,657 in 2019. However, this production has not been equipped with scientific data. This study aims to determined total phenolic content and $\mathrm{IC}_{50}$ of honey and propolis Trigona $\mathrm{sp}$. from North Lombok. Honey extracts are obtained using centrifugation techniques while propolis extracts using Ultrasound-assisted Extraction (UAE) method. Total phenolic content was analyze by Folin-ciocalteu method and determination of free radical activity was analyze by DPPH method. Total phenolic content of honey extract was $1.25 \pm 0.08 \mathrm{mg} \mathrm{GAE} / \mathrm{g}$, and the $\mathrm{IC}_{50}$ value was $1550 \pm 0.02 \mu \mathrm{g} / \mathrm{ml}$. The total phenolic content of propolis extract was $6.02 \pm 0.55 \mathrm{mg} \mathrm{GAE} / \mathrm{g}$, and the $\mathrm{IC}_{50}$ value was $493.3 \pm 0.01 \mu \mathrm{g} / \mathrm{ml}$.

\section{PENDAHULUAN}

Dewasa ini kerusakan akibat radikal bebas menjadi topik perhatian karena menimbulkan konsekuensi yang serius. Radikal bebas dapat berinteraksi dengan senyawa biologis yang ada dalam tubuh manusia seperti lemak, protein, dan DNA yang dapat merubah fungsi seluler dan menimbulkan berbagai penyakit. Penyakit akibat paparan radikal bebas diantaranya diabetes

http://dx.doi.org/10.23960/aec.v6.i1.2021.p74-82 
mellitus, gangguan neurodegeneratif (alzheimer, parkinson), penyakit kardiovaskular (aterosklerosis dan hipertensi), penyakit pernapasan (asma), katarak, artritis reumatoid, katarak, dan berbagai kanker (kolorektal, prostat, payudara, paru-paru, dan kandung kemih).

Madu dan Propolis dikenal memiliki berbagai aktivitas biologis salah satunya sebagai sumber antioksidan alami. Kemampuan madu dan propolis dalam mengahambat radikal bebas diperoleh dari berbagai senyawa seperti asam salisilat, asam benzoat, ester asam sinamat, fenolik, flavonoid, alkohol triterpen, komponen lipid, vitamin $\mathrm{C}, \mathrm{E}, \beta$-karoten dan berbagai kelompok enzim. Aktivitas kelompok senyawa ini dipengaruhi oleh berbagai faktor diantaranya letak geografis, spesies tanaman, waktu pemanenan, dan perilaku selektif lebah. Berbagai faktor perbedaan tersebut menyebabkan karakteristik aktivitas biologis yang dihasilkan beragam. Penelitian yang dilakukan oleh Agus dkk (2019) menyatakan perbedaan letak geografis menghasilkan aktivitas antioksidan yang berbeda. Hasil penelitian menyatakan madu Tetragonula laeviceps dari Kabupaten Sleman dan Klaten memiliki kadar fenolik total, kadar flavonoid total, dan aktivitas antioksidan yang lebih tinggi dibandingkan Kabupaten Nglipar Gunungkidul.

Budidaya lebah madu spesies Trigona sp. di wilayah Lombok terutama di daerah Lombok Utara semakin berkembang. Jumlah koloni lebah Trigona sp. pada tahun 2019 di daerah Kabupaten Lombok Utara mencapai 22.657 stup dengan produksi madu sejumlah 5.664 L dan propolis sejumlah $4.531 \mathrm{~kg}$ per tahunnya. Penggunaan madu dan propolis Trigona sp. asal Lombok Utara sebagai antioksidan alami sangat diperlukan untuk meningkatkan kualitas kesehatan masyarakat dengan efek samping yang rendah. Potensi madu dan propolis serta ketersediaan yang melimpah tersebut belum dilengkapi dengan data dan informasi ilmiah yang sangat dibutuhkan untuk membuktikan khasiat dan meningkatkan daya jual produk. Oleh karena

itu, penting dilakukan pengujian kadar fenolik total dan aktivitas antiradikal bebas dari madu dan propolis Trigona sp. asal Lombok Utara.

\section{METODE}

\section{Alat dan Bahan}

Alat utama yang digunakan dalam penelitian ini adalah sonikator, rotary evaporator, sentrifuga dan spektrofotometer UV-Vis. Bahan yang digunakan adalah madu dan propolis 
Trigona sp., DPPH (1,1-diphenyl-2-picrylhydrazyl), aquadest, etanol 96\%, metanol p.a, asam galat, kuersetin, reagen Folin-Ciocalteau, asam askorbat, serbuk $\mathrm{Na}_{2} \mathrm{CO}_{3}$.

\section{Prosedur}

\section{Penyiapan Bahan}

Madu dan propolis Trigona sp. diperoleh dari peternak lebah Kelompok Karya Muda, Dusun Lendang Gagak, Desa Sukadana, Kabupaten Lombok Utara. Madu diambil dengan cara mengikis bagian polen dan kantung madu, selanjutnya disaring untuk mendapatkan cairan madu murni. Madu yang diperoleh disimpan dalam wadah kaca pada suhu kamar. Propolis diambil dengan cara mengikis kerangka sarang lebah menggunakan pisau, selanjutnya propolis didinginkan pada suhu $-20{ }^{\circ} \mathrm{C}$ selama $24 \mathrm{jam}$. Propolis yang telah beku kemudian diblender hingga menjadi serbuk dan dimasukkaan ke dalam wadah kaca.

\section{Ekstraksi}

Sejumlah $500 \mathrm{~g}$ madu ditambahkan etanol 75\% (1:5) kemudian disentrifugasi dengan kecepatan $3000 \mathrm{rpm}$ selama 10 menit pada suhu $25^{\circ} \mathrm{C}$. Filtrat hasil sentrifugasi disaring dengan kertas saring Whatman No. 41, kemudian dipekatkan menggunakan rotary evaporator untuk menghasilkan ekstrak pekat. Sejumlah $300 \mathrm{~g}$ propolis bubuk ditambahkan dengan etanol $75 \%$ (1:10). Larutan selanjutnya diekstraksi dengan sonikator selama 20 menit pada suhu $20{ }^{\circ} \mathrm{C}$. Suspensi selanjutnya disaring menggukan kertas saring Whatman No.41 dan diuapkan menggunakan rotary evaporator untuk menghasilkan ekstrak pekat.

\section{Analisis Kadar Fenolik Total}

Sejumlah $0,1 \mathrm{~g}$ ekstrak madu dan propolis Trigona $s p$. dilarutkan hingga $10 \mathrm{~mL}$ menggunakan metanol p.a. Larutan ekstrak kemudian dipipet sebanyak $300 \mu$ l, ditambah $1 \mathrm{~mL}$ reagen Folin Ciocalteu, digojok dan didiamkan selama 3 menit. Sampel selanjutnya ditambahkan 1,2 $\mathrm{mL}$ larutan $\mathrm{Na}_{2} \mathrm{CO}_{3} 7,5 \%$ dan didiamkan pada range operating time di suhu kamar. Absorbansi larutan ekstrak diukur menggunakan spekrofotometer UV-Vis pada panjang gelombang maksimum. Kandungan fenolik total dalam sampel didapatkan dengan memasukkan nilai absorbansi ke dalam persamaan kurva baku asam galat dinyatakan dalam satuan GAE 
(Gallic Acid Equivalen), yaitu mg konsentrasi ekstrak per gram sampel (mg/g) yang dihitung menggunakan Formula 1.

$$
\text { Total fenol GAE }=c \frac{\mathrm{V}}{\mathrm{m}} \times 100 \%
$$

\section{Uji Aktivitas Penghambatan Radikal Bebas}

Uji aktivitas penghambatan radikal bebas dari ekstrak madu dan propolis Trigona $s p$. dilakukan menggunakan metode 1,1-difenil-2-pikrilhidrazil (DPPH) dengan asam askorbat (Vitamin C) dan kuersetin sebagai kontrol positif. Larutan pembanding dan larutan uji dari masing- masing konsentrasi dipipet $1 \mathrm{~mL}$, ditambahkan $1 \mathrm{~mL}$ DPPH kemudian dicukupkan dengan metanol p.a hingga $5 \mathrm{~mL}$. Larutan kemudian divortex selama 30 detik dan diinkubasi pada suhu $37^{\circ} \mathrm{C}$ selama operating time. Absorbansi diukur menggunakan spektrofotometer UVVis pada panjang gelombang maksimum yang diperoleh.

Aktivitas penangkalan radikal bebas dihitung sebagai persentase berkurangnya intensitas warna DPPH yaitu persen inhibisi yang diperoleh berdasarkan perhitungan menggunakan Formula 2.

$$
\% \text { inhibisi }=\frac{\text { Absorbani kontrol }- \text { Absorbansi sampel }}{\text { Absorbansi Kontrol }} \times 100 \%
$$

Nilai $\mathrm{IC}_{50}$ ditentukan melalui persamaan garis regresi linier yang menghubungkan $\%$ inhibisi dengan konsentrasi larutan uji tiap sampel. Nilai IC $_{50}$ menggambarkan konsentrasi ekstrak yang mampu menghambat $50 \%$ radikal bebas.

\section{HASIL DAN PEMBAHASAN}

Aktivitas antioksidan madu dan propolis Trigona sp. diketahui berasal dari kelompok senyawa flavonoid dan fenolik. Campuran etanol air dengan konsentrasi $70-75 \%$ berperan sebagai pelarut yang efektif untuk mengekstraski senyawa falvonoid dan fenolik, diikuti dengan pelarut lain seperti etil eter, air, metanol, heksana dan kloroform. Berdasarkan penelitan yang dilakukan oleh Sime et al., (2015), kadar tertitinggi dari polifenol dan flavonoid ada pada 
konsentrasi pelarut etanol 75\%. Selain itu, ekstrak etanol 75\% juga menunjukkan aktivitas antioksidan tertinggi yang diukur dengan metode DPPH, ABTS, FRAP, ORAC, dan CAA.

Larutan ekstrak madu dan propolis Trigona sp. dipekatkan menggunakan rotary evaporator pada suhu $40{ }^{\circ} \mathrm{C}$. Suhu penguapan diatas $45{ }^{\circ} \mathrm{C}$ dapat mengakibatkan degradasi termal yang mengakibatkan senyawa fenolik berkurang sehingga aktivitas antioksidan yang dihasilkan rendah. Karakteristik ekstrak beserta persentase rendemen madu dan propolis Trigona $s p$. dijabarkan pada Tabel 1. Besarnya rendemen yang diperoleh menggambarkan jumlah penarikan senyawa aktif pada sampel.

Tabel 1. Karakteristik dan persentase rendemen esktrak madu dan propolis Trigona sp.

\begin{tabular}{ccc}
\hline Sampel & Madu & Propolis \\
\hline Karakteristik & Ekstrak kental & Ekstrak kental, \\
& berwarna coklat & lengket dan \\
& keemasan & berwarna coklat \\
\% Rendemen & $32.3 \%$ & $21.62 \%$ \\
\hline
\end{tabular}

Analisis kadar fenolik total dari ekstrak madu dan propolis Trigona sp. dilakukan menggunakan metode Folin-ciocalteu. Metode ini merupakan metode yang paling umum digunakan karena proses pengujiannya yang cukup sederhana. Gugus hidroksil pada senyawa fenolik dapat mereduksi asam fosmolibdat-fosfotungstat dari reagen Folin-Ciocalteu membentuk kompleks molibdenum-tungstat (Mo-W) berwarna biru. Semakin besar konsentrasi senyawa fenolik yang terkandung di dalam sampel, maka semakin banyak ion fenolat yang akan mereduksi asam heteropoli sehingga warna biru yang dihasilkan semakin pekat.

Tabel 2. Nilai kadar fenolik total ekstrak madu dan propolis Trigona sp. asal Lombok Utara dan beberapa wilayah lainnya.

\begin{tabular}{|c|c|c|c|c|c|}
\hline Ekstrak & $\begin{array}{c}\text { Lombok } \\
\text { Utara }\end{array}$ & $\begin{array}{c}\text { Sulteng } \\
\text { (Sumarlin } \\
\text { dkk., 2018) }\end{array}$ & $\begin{array}{c}\underset{\text { Jatim }}{\text { (Rosyidi }} \\
\text { dkk., 2018) }\end{array}$ & $\begin{array}{c}\text { Kalbar } \\
\text { (Yuliana } \\
\text { dkk., 2013) }\end{array}$ & $\begin{array}{c}\text { Johor } \\
\text { (Ya'akob } \\
\text { dkk., 2019) }\end{array}$ \\
\hline & \multicolumn{5}{|c|}{ (mg GAE/g) } \\
\hline Madu & $1,25 \pm 0,08$ & $\begin{array}{c}1,0096 \\
\pm 0,1170\end{array}$ & - & - & $0,04-0,1$ \\
\hline Propolis & $6,02 \pm 0,55$ & - & $9,603-15,17$ & $97,4 \pm 0,2$ & - \\
\hline
\end{tabular}

http://dx.doi.org/10.23960/aec.v6.i1.2021.p74-82 
Kadar fenolik total ekstrak madu dan propolis Trigona sp. asal Lombok Utara dan beberapa wilayah lainnya ditunjukkan pada Tabel 2. Kadar fenolik total madu Trigona sp. dari daerah Lombok Utara sebesar 1,25 \pm 0,08 $\mathrm{mg}$ GAE/g dan kadar fenolik total dari ekstrak propolis Trigona $s p$. adalah 6,02 0,55 mg GAE/g. Nilai kadar fenolik total madu Trigona sp. asal Lombok Utara menyerupai kadar fenolik total madu Trigona sp. asal Sulawesi Tengah yaitu 1,0096 \pm 0,1170 mg GAE/g. Hasil kadar fenolik total ekstrak propolis Trigona sp. asal Lombok Utara lebih rendah dibandingkan propolis Trigona sp. asal Jawa Timur dan Kalimantan Barat dengan nilai fenolik total secara berturut-turut 9,603-15,17 mg GAE/g dan 97,4 \pm 0,2 mg GAE/g. Jika dibandingkan dengan madu Trigona $s p$. yang berada di luar negeri, total fenolik ekstrak madu asal Lombok Utara terbilang lebih tinggi. Ya'kob dkk., (2019) dalam penelitiannya mendapatkan nilai total fenolik madu asal Johor, Malaysia berkisar antara 0,04-0,1 mg GAE/g.

Kadar fenolik total dari ekstrak madu dan propolis Trigona sp. di berbagai daerah sebagian besar dipengaruhi oleh jenis tanaman yang dijadikan sebagai sumber pakan lebah. Jenis tanaman tersebut berbeda-beda tergantung pada letak geografisnya. Asal tanaman dapat mempengaruhi parameter fisikokimia yang menentukan kualitas dari madu dan propolis. Kadar senyawa fenolik total dapat menggambarkan sifat antioksidan dari sampel dikarenakan senyawa fenolik memiliki gugus hidroksil yang dapat menetralisir radikal bebas. Semakin tinggi kadar fenolik total pada sampel, maka semakin kuat aktivitas penghambatan radikal bebas yang dihasilkan. Senyawa fenolik juga dilaporkan memiliki aktivitas biologis lainnya seperti antiinflamasi, antiproliferasi, dan antimikroba

Uji aktivitas antiradikal bebas pada ekstrak madu dan propolis Trigona sp. dilakukan menggunakan metode DPPH (1,1-diphenyl-2-picrylhydrazyl). Metode ini sederhana, mudah, akurat, dan sensitif pada evaluasi antioksidan dalam jus buah, ekstrak tumbuhan, dan zat murni seperti flavonoid dan terpenoid. Metode DPPH juga meminimalisir penggunaan reagen dan sampel karena membutuhkan volume pengujian yang sedikit. DPPH merupakan radikal bebas bersifat stabil yang dapat bereaksi dengan suatu senyawa antioksidan. Radikal DPPH yang tersisa diukur dengan spektrofotometer UV-Vis untuk menentukan nilai $\mathrm{IC}_{50}$.

Nilai IC $_{50}$ merupakan parameter utama dalam menggambarkan aktivitas penghambatan radikal bebas. Nilai tersebut menggambarkan konsentrasi dari substansi antioksidan pada ekstrak yang dapat mereduksi 50\% radikal bebas. Semakin kecil nilai $\mathrm{IC}_{50}$ maka semakin kuat aktivitas penangkalan radikal bebas yang dimiliki. Kapasitas penangkalan radikal bebas berdasarkan nilai 
$\mathrm{IC}_{50}$ diklasifikasikan ke dalam 4 grup yaitu antioksidan kuat $(50-100 \mu \mathrm{g} / \mathrm{ml})$, menengah (100-150 $\mu \mathrm{g} / \mathrm{ml})$, lemah $(150-200 \mu \mathrm{g} / \mathrm{ml})$, dan sangat lemah (>200 $\mu \mathrm{g} / \mathrm{ml})$. Nilai IC $_{50}$ madu dan propolis asal Lombok Utara dan beberapa wilayah lainnya ditunjukkan pada Tabel 3.

Tabel 3. Nilai $\mathrm{IC}_{50}$ madu dan propolis asal Lombok Utara dan beberapa wilayah lainnya

\begin{tabular}{ccc}
\hline \multirow{2}{*}{ Daerah } & Madu & Propolis \\
\cline { 2 - 3 } & \multicolumn{2}{c}{$\mathrm{IC}_{50}(\mu \mathrm{g} / \mathrm{ml})$} \\
\hline Lombok Utara & $1550 \pm 0,02$ & $493,3 \pm 0,01$ \\
Sulawesi Selatan (Djakaria dkk., 2020) & $398,57 \pm 3,47$ & - \\
Bali (Leliqia et al., 2020) & $14,560 \pm 0,25$ & - \\
Makassar (Hasan dkk., 2014) & - & $1125,56 \pm 133$ \\
Pekanbaru (Hasan dkk., 2014) & - & $308,88 \pm 12$ \\
Kendal (Hasan dkk., 2014) & - & $144,06 \pm 52,53$ \\
Pandeglang (Hasan dkk., 2014) & - & $68,93 \pm 5,63$ \\
Banjarmasin (Hasan dkk., 2014) & - & $4162,61 \pm 845,9$ \\
\hline
\end{tabular}

Ektrak madu dan propolis Trigona $s p$. asal Lombok Utara memiliki nilai $\mathrm{IC}_{50}$ secara berturut turut sebesar $1550 \pm 0,02 \mu \mathrm{g} / \mathrm{ml}$ dan 493,3 $\pm 0,01 \mu \mathrm{g} / \mathrm{ml}$. Berdasarkan parameter aktivitas antioksidan yang dikemukakan oleh Djakaria dkk., (2020), madu dan propolis Trigona $s p$. asal lombok Utara memiliki aktivitas antioksidan yang sangat lemah dilihat dari nilai $\mathrm{IC}_{50}$ yang tinggi $(>200 \mu \mathrm{g} / \mathrm{ml})$. Nilai $\mathrm{IC}_{50}$ yang tinggi dapat disebabkan oleh zat pereduksi yang terkandung di dalam sampel madu dan propolis Trigona sp. Zat tersebut merupakan kelompok gula dan asam amino yang dapat menganggu nilai absorbansi sehingga terjadi kesalahan dalam penentuan aktivitas antioksidan. Komponen tersebut dapat dihilangkan melalui pemurnian sampel dilanjutkan dengan ektraksi mengggunakan pelarut selektif (fraksinasi). Zat pereduksi tersebut dihilangkan untuk mendapatkan hasil aktivitas penangkalan radikal bebas yang lebih akurat.

Nilai IC 50 ekstrak madu Trigona sp. asal Lombok Utara lebih tinggi dibandingkan dengan madu Trigona sp. asal Sulawesi Selatan. Berbeda dengan penelitian yang dilakukan oleh Leliqia (2020), nilai IC $_{50}$ dari madu Trigona $s p$. asal Bali lebih tinggi dari madu asal Lombok Utara. Hasan dkk., (2014) melakukan analisis aktivitas antioksidan ekstrak propolis Trigona sp. dari 5 daerah di Indonesia yaitu Makassar, Pekanbaru, Kendal, Pandeglang, dan Banjarmasin yang memiliki Nilai $\mathrm{IC}_{50}$ yang berbeda-beda. Nilai $\mathrm{IC}_{50}$ ekstrak propolis asal Lombok Utara lebih rendah dibandingkan dengan ekstrak propolis Trigona sp. asal Makassar dan Banjarmasin namun lebih tinggi dibandingkan dengan propolis Trigona sp. asal Pekanbaru, Kendal, dan Pandeglang.

http://dx.doi.org/10.23960/aec.v6.i1.2021.p74-82 
Berdasarkan data yang telah dijabarkan, diketahui bahwa letak geografis dari madu dan propolis Trigona sp. dapat mempengaruhi aktivitas penangkalan radikal bebas dari sampel. Hal ini dibuktikan oleh penelitian yang dilakukan oleh Agus dkk (2019) yang menyatakan perbedaan letak goegrafis dapat mempengaruhi nilai kadar fenolik total dan aktivitas antioksidan secara signifikan. Bankova dkk., (2002) menyatakan bahan aktif sebagai sumber aktivitas biologis dari propolis dan madu Trigona sp. dapat bervariasi tergantung pada asal tumbuhan, cuaca, serta waktu pemanenan. Kuś dan Jerković (2018) juga menyatakan komposisi dan kapasitas antioksidan madu bergantung pada cara pengolahan madu. Selain itu, intensitas warna juga dapat mempengaruhi aktivitas biologis dari sampel. Semakin gelap warna madu dan propolis maka semakin tinggi kadar senyawa fenolik total dan aktivitas antioksidannya.

Aktivitas penghambatan radikal bebas dari madu dan propolis Trigona sp. berasal dari senyawa fenolik (flavonoid dan asam fenolat), serta non-fenolat (asam askorbat, zat seperti karotenoid, asam organik dan asam amino, serta enzim protein tertentu seperti glukosa oksidase dan katalase). Kelompok senyawa polifenol merupakan senyawa antiradikal bebas utama dalam madu dan propolis. Senyawa polifenol efektif sebagai penangkal radikal bebas karena memiliki struktur molekuler berupa cincin aromatik dengan gugus hidroksil yang mampu mereduksi radikal bebas. Radikal bebas bersifat kurang reaktif sehingga proses peroksidasi lipid terhambat.

\section{KESIMPULAN}

Kadar senyawa fenolik total madu Trigona $s p$. asal Lombok Utara sebesar 1,25 \pm 0,08 $\mathrm{mg}$ GAE/g dan propolis Trigona sp. asal Lombok Utara sebesar 6,02 \pm 0,55 mg GAE/g. Ekstrak madu dan propolis Trigona sp. asal Lombok Utara terbukti memiliki aktivitas antioksidan terlihat dari Nilai $\mathrm{IC}_{50}$ yang diperoleh. Nilai $\mathrm{IC}_{50}$ dari ekstrak madu Trigona $s p$. asal Lombok Utara sebesar $1550 \pm 0,02 \mu \mathrm{g} / \mathrm{ml}$ dan propolis Trigona $s p$. asal Lombok Utara 493,3 $\pm 0,01$ $\mu \mathrm{g} / \mathrm{ml}$.

http://dx.doi.org/10.23960/aec.v6.i1.2021.p74-82 


\section{DAFTAR PUSTAKA}

Agus, A. et al., 2019, Evaluation of antioxidant activity, phenolic, flavonoid and Vitamin C content of several honeys produced by the Indonesian stingless bee: Tetragonula laeviceps, Livestock Research for Rural Development., Vol. 31, No. 10

Bankova, V. et al., 2002, Chemical composition of European propolis: Expected and unexpected results, Zeitschrift fur Naturforschung - Section C Journal of Biosciences., Vol. 57, No. 56, 530-533.

Djakaria, S. A., Batubara, I. and Raffiudin, R., 2020, Antioxidant and Antibacterial Activity of Selected Indonesian Honey against Bacteria of Acne, Jurnal Kimia Sains dan Aplikasi., Vol. 23, No. 8, 267-275.

Hasan, A. E. Z. et al., 2014, Investigating the Antioxidant and Anticytotoxic Activities of Propolis Collected from Five Regions of Indonesia and Their Abilities to Induce Apoptosis, Emirates Journal of Food and Agriculture., Vol. 26, No. 5, 390-398.

Kuś, P. M., dan Jerković, I., 2018, New sample preparation method for honey volatiles fingerprinting based on Dehydration Homogeneous Liquid-Liquid Extraction (DHLLE), Molecules., Vol. 23, No. 7.

Leliqia, N. P. E. et al., 2020, Aktivitas Antioksidan Kombinasi Fraksi Metanol Virgin Coconut Oil dan Madu Kele Bali dengan Metode DPPH (2 , 2- diphenyl -1-picrylhidrazyl), Journal of Pharmaceutical Science and Clinical Research., Vol. 2020, No. 2, 84-96.

Rosyidi, D. et al., 2018, Perbandingan Sifat Antioksidan Propolis Pada Dua Jenis Lebah ( Apis mellifera dan Trigona sp.) Di Mojokerto Dan Batu, Jawa Timur, Indonesia. Jurnal Ilmu dan Teknologi Hasil Ternak., Vol. 13, No. 2, 108-117.

Sime, D. et al., 2015, Total phenols and antioxidant activities of natural honeys and propolis collected from different geographical regions of Ethiopia, Bulletin of the Chemical Society of Ethiopia. Vol. 29, No. 2.

Sumarlin, L. O. et al., 2018, Aktivitas Antioksidan Kombinasi Madu Monoflora dengan Ekstrak Daun Namnam (Cynometra cauliflora L.), La', Alchemy : Journal of Chemistry., Vol. 6, No. 1, 10-17.

Ya'akob, H. et al., 2019, Evaluation of Physicochemical Properties of Trigona sp . Stingless Bee Honey from Various Districts of Johor, Jurnal Kejuruteraan SI., Vol. 2, No. 1,. 59-67.

Yuliana, N. D., Wijaya, C. H. dan Nasrullah, N., 2013, Classification of Trigona sp bee propolis from four regions in Indonesia using FTIR metabolomics approach, 13th Asean Food Conference., 2013. 9-11.

http://dx.doi.org/10.23960/aec.v6.i1.2021.p74-82 